\title{
Reversal of Protein-Losing Enteropathy with Heparin Therapy in an Adult Patient with Congenital Heart Disease
}

\author{
Takao Tsuzuki $^{\mathrm{a}}$ Hiroyuki Okada ${ }^{\mathrm{a}}$ Ryuta Takenaka ${ }^{\mathrm{a}}$ Yoshiro Kawahara ${ }^{\mathrm{a}}$ Jun Kato ${ }^{\mathrm{a}}$ \\ Hiroaki Okazaki $^{\text {b }}$ Hirofumi Kawamoto $^{a}$ Yasushi Shiratori ${ }^{a}$ \\ a Department of Gastroenterology and Hepatology, Okayama University Graduate School of Medicine, \\ Dentistry and Pharmaceutical Sciences, and ${ }^{\text {b}}$ Fujita Hospital, Okayama, Japan
}

Dear Sir,

Protein-losing enteropathy (PLE) is defined as the excessive loss of plasma proteins through the intestine [1]. PLE can result from a number of diseases, including congenital heart malformations. PLE after heart surgery, especially a Fontan opera- tion, is a serious problem because PLE reportedly occurs in up to $13.4 \%$ of patients, within 10 years of receiving a Fontan operation [2]. Surgical and medical treatments have been reported to be effective in only $60 \%$ of PLE cases, and the total mor- tality rate has been found to be as high as $50 \%$ [3]. Recently, heparin therapy has been reported to improve the symptoms of PLE [4]. Nearly all reports regarding heparin therapy for PLE involve child cases. In this report, we describe the successful use

Fig. 1. Clinical course.

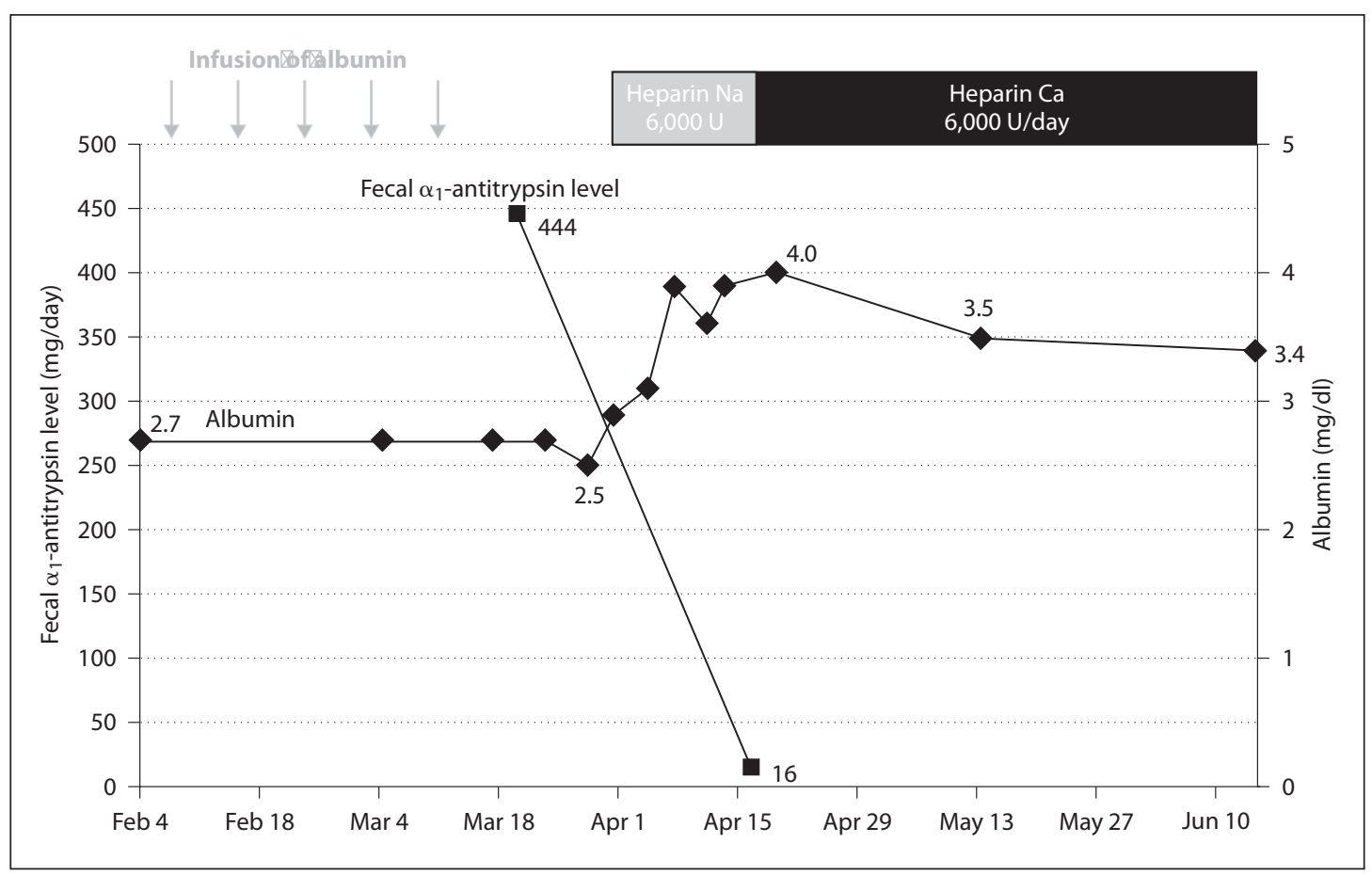

\section{KARGER}

Fax +41613061234 E-Mail karger@karger.ch www.karger.com

\section{(C) 2006 S. Karger AG, Basel} 0012-2823/06/0744-0206\$23.50/0

Accessible online at: www.karger.com/dig
Takao Tsuzuki

Department of Gastroenterology and Hepatology

Okayama University Graduate School of Medicine, Dentistry and

Pharmaceutical Sciences, 2-5-1 Shikata-cho, Okayama 700-8558(Japan)

Tel. +81 86235 7219, Fax +81 86225 5991, E-Mail takaotsuzuki@ybb.ne.jp 
of heparin to treat PLE in an adult case, which represents the oldest case yet reported.

\section{Case Report}

A 25-year-old man diagnosed as having congenital pulmonary stenosis underwent a Fontan operation at the age of 6 years. At the age of 14 years, symptomatic PLE developed. Since that time, the patient had experienced hypoalbuminemia, despite intravenous albumin replacement, steroid therapy and mediumchain triglyceride diets. In September 2003, he suffered from septicemia due to cellulites caused by progressive edema with hypoalbuminemia, and steroid therapy was discontinued. The patient subsequently entered a state of PLE requiring albumin administration 2-3 times per month.

In March 2005, he was admitted to our hospital for heparin therapy. A technetium-99m-human serum albumin labeled dextran scintiscan demonstrated abnormal accumulations of radioactive tracer in patches of the small intestine. Gastroscopy and colonoscopy showed no findings, and intestinal lymphangiectasia, which is sometimes found with PLE, was not detected.
After a 2-week intravenous administration of heparin at a dose of 6,000 U/day, the patient's serum albumin level had increased from 2.7 to $3.9 \mathrm{~g} / \mathrm{dl}$ without intravenous infusion of seroalbumin. The fecal $\alpha_{1}$-antitrypsin level had decreased from 444 to $16 \mathrm{mg} /$ day by the 18 th day of treatment. On the 17th day of treatment, the method of heparin administration was changed to subcutaneous injection to allow self-injection, and the serum albumin level remained above $3.4 \mathrm{~g} / \mathrm{dl}$ thereafter. The prothorombin and partial thromboplastin times remained normal, and no adverse reaction was observed. After discharge, the patient is continuing self-injection of heparin in an outpatient setting, and his serum albumin level has been maintained above $3.5 \mathrm{~g} / \mathrm{dl}$, without albumin administration (fig. 1).

\section{Discussion}

The pathophysiology of PLE is not yet completely understood. Recently, several investigators have reported that the absence of heparin sulfate proteoglycans in the basolateral surfaces of intestinal epithelial cells is associated with PLE [4]. Other factors such as lymphangiectasias caused by an increased central venous pressure [5] and an inflammatory response in the intestinal wall [6] have also been described.
Heparin therapy has been adopted in a limited number of patients, and the optimal dosage, adequate regimen and longterm results are still unknown. Further experience and additional studies are necessary to prove the efficacy of heparin therapy for PLE.

\section{References}

1 Beeken WL, Busch HJ, Sylwester DL: Intestinal protein loss in Crohn's disease. Gastroenterology 1972;62:207-215.

2 Feldt RH, Driscoll DJ, Offord KP, Cha RH: Protein-losing enteropathy after the Fontan operation. J Thorac Cardiovasc Surg 1996; 112:672-680.

3 Mertens L, Hagler DJ, Sauer U, Somerville J: Protein-losing enteropathy after the Fontan operation: an international multicenter study. J Thorac Cardiovasc Surg 1998;115: 1063-1073.

4 Donnelly JP, Rosenthal A, Castle VP, Holmes RD: Reversal of protein-losing enteropathy with hepatin therapy in three patients with univentricular hearts and Fontan palliation. J Pediatr 1997;130:474-478.

5 Warnes C, Feldt R, Hagler D: Protein-losing enteropathy after the Fontan operation: successful treatment by percutaneous fenestration of the atrial septum. Mayo Clin Proc 1996;71:378-379.

6 Lenz D, Hambsch J, Schneider P, Hausler HJ, Sauer U, Hess J, Tarnok A: Protein-losing enteropathy in patients with Fontan circulation: is it triggered by infection? Crit Care 2003;7:185-190. 